\title{
Split Memory: The Geography of Holocaust Memory and Amnesia in Belarus
}

\author{
Anika Walke
}

"Za Dvinoi." Beyond the Dvina, the river. The location of the mass grave of the Jews of Beshankovichy is known: it is not here, but over there. The mass grave is hard to find. A local guide who knows where it is, however, can lead the way. One crosses the river across a pontoon bridge because the region does not have enough money to build a permanent one. On the other side of the Dvina, one needs to walk up a rather steep hill and then continue on for another ten minutes on a gravel road to reach the forest. Once there, it is best to follow a narrow trench to one's right. Forest rangers dug the trench to stop the spread of eventual forest fires. About two hundred meters from the nearest gravel road, a frail, bent, and partially collapsed fence guards a square of about four by six meters. In the middle of the fenced-in area is a memorial stone, roughly in the shape of an obelisk, with an inscription in Yiddish and Russian (see Figure 1): "To the eternal memory of 1,068 Soviet citizens who were killed by the Hitlerites on February 11, 1942. From relatives and zemliaki (townsmen)."1

As was common in the Soviet Union at the time of the memorial's establishment, the national identity of the Jewish victims could not be named. The remote location of the mass grave, the final resting place for over a thousand local Jews, reflects the exclusion they faced during the German occupation from July 1941 to February 11, 1942, when they were murdered. It also removes their memory from the center of the town of Beshankovichy, away from the living, away from other commemorative sites related to the occupation and World War II. ${ }^{2}$ It is also in sharp contrast to the presence of Jews before June 1941, when they were a vital element of local society and shaped the economic, cultural, and social life of the town.

Beshankovichy, now a town of about 6,700 residents, shows the deep divisions of the memory of war and genocide in Belarus, expressed clearly in spatial terms. ${ }^{3}$ The literal and figural distance between historical sites of life before and during the genocide on the one hand, and sites of memory and

I am grateful to Anne Knowles, Erin McGlothlin, Harriet Murav, Trevor Sangrey, and the anonymous reviewers of Slavic Review for their comments on earlier drafts of this article. I am indebted to Olga Shparaga, Aleksei Bratochkin, Irina Makhovskaia, and Stanislav Leonenko for their generous support and many meaningful discussions during my recent visits to Belarus.

1. Photo by author, Beshankovichy, 2015.

2. Beshankovichy, also spelled Beshenkovichy, from Бешанко́вічы (Belarusian spelling) or Бешенко́вичи (Russian spelling), is located 32 miles west of Vitebsk.

3. Chislennost' naseleniia na 1 ianvaria 2016g. i srednegodovaia chislennost' naseleniia za 2015 god po Respublike Belarus' v razreze oblastei, raionov, gorodov i poselkov gorodskogo tipa (Natsional'nyi statisticheskii komitet Respubliki Belarus', 2016), http://www.belstat.gov.by/ofitsialnaya-statistika/solialnaya-sfera/demografiya_2/ metodologiya-otvetstvennye-za-informatsionnoe-s_2/index_4945/ (last accessed October 27, 2016). 


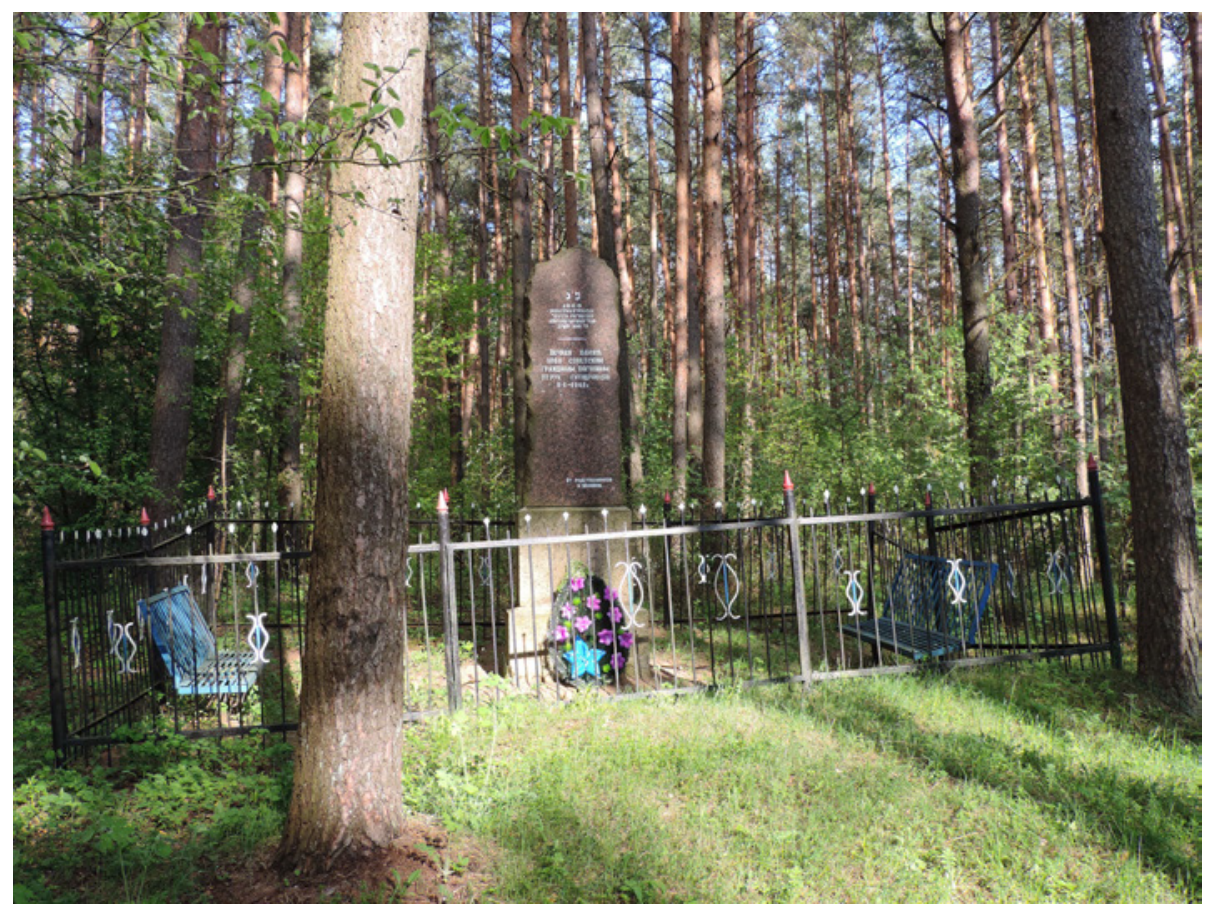

Figure 1. Memorial "To the eternal memory of 1,068 Soviet citizens who were killed by the Hitlerites on February 11, 1942. From relatives and zemliaki (townsmen)” (1958). Photo: Anika Walke, Beshankovichy 2015.

commemoration on the other, reflects the divisions of communal memory in Belarus. Recognizing this distance is possible only by listening to the stories people tell about their life and the life of their community, and about how they deal with the past. Oral histories and other testimonies suggest that the experience of German occupation and Nazi genocide is located in specific places that are not, or are only partially, included in the geography of local commemoration. This split adds a layer of silence to the layers of violence, persecution, and destruction that characterized the treatment of Soviet Jews during the German occupation.

In my ongoing research, I try to understand how such divisions emerge, and what they tell us about the ways in which local communities live with and in the aftermath of genocide. ${ }^{4}$ I utilize archival documentation, interviews and testimonies, and a variety of other sources to take note of the violence and shared suffering experienced by residents of German-occupied Soviet territories, and of the fact that the genocide in part relied on, and included, local participation. This article suggests that the spatial division reflects the trauma of loss as much as shame, silence, and perhaps continued resentment against those who suffered at the hands of both German occupants and local helpers. In the end, I hope that the research can help open up a conversation

4. This work builds on a previous book, Anika Walke, Pioneers and Partisans: An Oral History of Nazi Genocide in Belorussia (New York, 2015). 
about how we live with the legacy of violence, in particular, a genocide that was embedded in a war that targeted the whole population. I also question how the experience of some people is written out of history and memory and how we can counter this process. ${ }^{5}$

Developing this in-depth perspective on the history and memory of the Nazi genocide is an extension of scholarship on the commemoration of World War II in the Soviet Union. For a long time, such studies focused on the statesanctioned portrayal of the war as rendered in historiography and centralized memorial culture that foregrounded victory and military heroism and institutionalized the marginalization of Holocaust memory in postwar Soviet society. In recent years, however, more and more scholars have turned to the local dynamics of commemoration to gain new insights into the legacy of the genocide among the Soviet populace. ${ }^{6}$ Such studies are necessary in a region where "almost every town ... has its [Babi Yar]," that is, where there is a killing site of Jews in or close by to nearly every settlement. ${ }^{7}$ This "relentless taint of death," the presence of mass graves in fields, forests, wells, mines, or hastily dug pits and trenches in the landscapes of not only formerly Soviet territories but much of eastern and central Europe more generally, has recently received awareness among scholars of different disciplines. ${ }^{8}$ Simultaneously, a number of initiatives and organizations including the well-known French organization Yahad-In Unum aim to identify and document Jewish killing sites. ${ }^{9}$ Often, such initiatives lay the groundwork for memorializing the victims of mass shootings; in Belarus and Lithuania, since the early 2000s a number of memorials have been placed on previously unmarked gravesites. ${ }^{10}$ The efforts

5. On the overall dynamics, policies, and outcomes of the German attack and occupation of what is now the Republic of Belarus, see Christian Gerlach, Kalkulierte Morde: Die deutsche Wirtschafts- und Vernichtungspolitik in Weißrussland, 1941 bis 1944 (Hamburg, 2000); Bernhard Chiari, Alltag hinter der Front: Besatzung, Kollaboration und Widerstand in Weißrussland 1941-1944 (Düsseldorf, 1998).

6. Rebecca L. Golbert, "Holocaust Sites in Ukraine: Pechora and the Politics of Memorialization," Holocaust and Genocide Studies 18, no. 2 (Fall 2004): 205-33; Elena Makhotina, "Between 'Suffered' Memory and 'Learned' Memory: The Holocaust and Jewish History in Lithuanian Museums and Memorials After 1990," Yad Vashem Studies 44, no. 1 (2016): 207-46.

7. Wila Orbach, "The Destruction of the Jews in the Nazi-Occupied Territories of the USSR," Soviet Jewish Affairs 6, no. 2 (1976), 23. Orbach spells the name of the ravine near Kiev where more than 33,000 Jews were shot in September 1941, "Baby Yar," but nowadays Babii Iar or Babi Yar are more commonly used.

8. Gabriel Finder and Judith R. Cohen, "Memento Mori: Photographs from the Grave," in Gabriel Finder, Natalia Aleksiun, Antony Polonsky, and Jan Schwarz, eds., Making Holocaust Memory. POLIN: Studies in Polish Jewry 20 (Oxford, 2008), 73. See also Martin Pollack, Kontaminierte Landschaften (Vienna, 2014); Jessica Rapson, Topographies of Suffering: Buchenwald, Babi Yar, Lidice (New York, 2015).

9. See Patrick Desbois, "Yahad-In -Unum's Research of Mass Grave Sites of Holocaust Victims," in International Holocaust Remembrance Alliance, ed., Killing Sites: Research and Remembrance (Berlin, 2015), 87-96. A more comprehensive portrayal of the efforts and Father Desbois' perspective is in Patrick Desbois, The Holocaust by Bullets: A Priest's Journey to Uncover the Truth Behind the Murder of 1.5 Million Jews (New York, 2008).

10. A number of recently erected memorials in Vitebsk oblast, Belarus are listed in Arkadii Shul'man and Larissa Platonova, eds., Vsegda v nashei pamiati (Minsk, 2010). For Belarus, see the Belarus Holocaust Memorials Project at http://www.belarusmemorials.com 
to uncover these sites of murder regularly include the study of the process of occupation, ghettoization, round-up, and extermination, often in rural areas. Ghettos and other forms of persecution in villages and small towns are still understudied; this article takes up some questions broached in a few recent analyses attempting to fill this gap. ${ }^{11}$ It does so by integrating the study of prewar, wartime, and postwar experiences to probe how relationships within the community shifted and what these shifts can tell us about the possibility and aftermath of genocide. Space and place serve as key categories for this endeavor, since they are the literal and figural ground on which relationships are built and severed. How people relate to distinct places associated with particular meaning, such as former synagogues or Jewish schools, or fields and forests that have been altered by events or behaviors such as the digging of pits and burying of bodies in large numbers, sheds light on the construction of memory in ways that are both tangible and require interpretation. So far, scholarship on the link between violence, landscape, and memory has been primarily conducted with regard to instances of systematic violence outside of Europe. ${ }^{12}$ This article suggests that such a lens may elucidate problems of historical and political relevance such as the dynamics and the memory of the Nazi genocide in small, geographically-contained localities in formerly German-occupied Soviet territories. In essence, I adopt the perspective that "[i]n many cases, the modern form of a site is a physical manifestation of how the Holocaust is, and has been, viewed." 13 Examining the built environment or memorials and museums and how people behave in and around them, we may be able to discern societal changes, perceptions of particular groups, or simply the knowledge about a given site's history. ${ }^{14}$ Tracing what sites of murder looked like in the past and what they look like today allows us to reckon with the contaminated landscapes. ${ }^{15}$

The research presented here expands the understanding of "site" to include a whole town, not only a killing site. Considering the layout of memorials in relation to where war and genocide took place, and to prewar dwellings of the

(last accessed February 7, 2017). See also Makhotina, "Between 'Suffered' Memory and 'Learned' Memory," 229; and Killing Sites: Research and Remembrance, for discussions of identifying and memorializing mass graves in Ukraine, Belarus, Lithuania, Poland, and Croatia.

11. Yehuda Bauer, The Death of the Shtetl (New Haven, 2009); Martin Dean, "Lebensbedingungen, Zwangsarbeit und Überlebenskampf in den kleinen Ghettos: Fallstudien aus den Generalkommissariaten Weißruthenien und Wolhynien-Podolien," in Christoph Dieckmann and Babette Quinkert, eds., Im Ghetto, 1939-1945: Neue Forschungen zu Alltag und Umfeld (Göttingen, 2009), 54-73; Jan Grabowski, "Rural Society and the Jews in Hiding: Elders, Night Watches, Firefighters, Hostages and Manhunts," Yad Vashem Studies 40, no. 1 (2012): 49-74.

12. Kenneth E. Foote, Shadowed Ground: America's Landscapes of Violence and Tragedy (Austin, TX, 1997); Estela Schindel and Pamela Colombo, eds., Space and the Memories of Violence: Landscapes of Erasure, Disappearance and Exception (New York, 2014); James A. Tyner, Landscape, Memory, and Post-Violence in Cambodia (London, 2017). Foundational for many of these analyses is Simon Schama, Landscape and Memory (New York, 1995).

13. Caroline Sturdy Colls, Holocaust Archaeologies: Approaches and Future Directions (Cham, 2015), 14.

14. Ibid.

15. Pollack, Kontaminierte Landschaften, 43. 
victims of mass murder, illuminates not only how Holocaust memory is constructed (or not) but how a particular community relates to sites of violence and a disappearing past. Moreover, triangulating the geographies of experience and memory in a small Belarusian town uncovers how local relationships between Jews and non-Jews shifted over the course of 85 years: from amicable relations before the German occupation to resurgent antisemitism during the occupation to the complete oblivion of the Jewish residents, who were murdered in 1942. In sum, this approach contributes to the study of the systematic extermination of Soviet Jewry, which decimated the Jewish population of Belarus by $80 \%$, and its long aftermath. The study reveals that postwar indifference toward the sites where Jews were systematically killed signals a local community's problematic relationship to their own history of participating in and profiting from the extermination of their Jewish neighbors.

\section{Oral History, Testimony, and Historical and Mnemonic Space}

My interest in Beshankovichy and its geography of memory originates in several interviews I conducted with Leonid (Lazar) L'vovich Gol' braikh between 2002 and $2005 .{ }^{16}$ Gol' braikh (born 1931) had grown up in Beshankovichy and, like the more than 1,100 Jews in town, had been trapped behind the frontline after German troops occupied the town in Vitebsk oblast in early July 1941. It is hard to know exactly how many Jews were in Beshankovichy at the time, since several hundred refugees from Poland had settled in the town as well, but an unknown number of them and local residents managed to flee. ${ }^{17}$ When the mass execution of the town's Jews took place in February 1942, Gol' braikh escaped from the site of the shooting and found shelter in the home of family friends. ${ }^{18}$ Eventually, he joined a Soviet partisan unit and survived the war in its ranks. When the war ended, he did not stay in Beshankovichy, but moved to Leningrad.

The choice not to remain in their hometowns was common among survivors at the end of the war. The specter of violence played a large role in this decision. For one, young people like Gol'braikh had lost all relatives and had no one to turn to. In addition, the knowledge and memory of what had happened during the war-stigmatization, ghettoization, and extermination, partly at the hands of locals-were closely tied to particular places and sites. Survivors recalled that locals had participated in the assault on their Jewish neighbors and could not stand the thought of interacting with

16. Leonid L'vovich Gol'braikh, interviews, Pushkin (near St. Petersburg), May 5, 2001, September 3, 2002, and May 11, 2005.

17. Lev Iudovin, "Legendy i byli Beshenkovichei," Na Kacheliakh vremeni: Ocherki, ed. Arkadii Shulman (Minsk, 2009), 63.

18. For a concise summary of the events related to the persecution and extermination of Jews in Beshankovichy, see Daniel Romanovsky, "Beshankovichy," in Martin Dean and Mel Hecker, eds., United States Holocaust Memorial Museum Encyclopedia of Camps and Ghettos, 1933-1945, Vol. II: Ghettos in German-Occupied Eastern Europe (Bloomington, 2012), 1647-49. Survivors in Poland dealt with similar issues and came to various conclusions about staying or leaving, see Finder and Cohen, "Memento Mori," 58, and 58n5. 
them on a regular basis. ${ }^{19}$ Secondly, the German occupation regime had reworked familiar places into genocidal landscapes. ${ }^{20}$ Remaining in place would have been a constant reminder of the violence, since the space itself had been reshaped by the violence and carried disturbing meaning. ${ }^{21}$ Rita Kazhdan explained her desire to move out of a particular home her uncle had rented in the summer of 1944: "For him, this did not mean anything. But for me it was ghetto." 22 Her uncle, who had not lived in Minsk during the war, did not know-had not seen-that in the streets around his new home thousands of people had been humiliated, chased, and killed. He did not know that young Rita had last seen her mother walking along one of the ghetto streets before she was taken away and shot at the "Iama," a pit in the middle of the city. Knowledge about this violence, which is absent, or invisible, yet present in memory, adds the specter of violence to the experience of the place that used to be home by triggering an affective reaction. ${ }^{23}$ Visiting the killing site in Beshankovichy, for instance, made Leonid Gol'braikh "go weak at the knees." ${ }^{24}$ In other words, the experience of his hometown was haunted by the ways in which power had worked on subjects and their social worlds, in this case, the genocide of Beshankovichy's Jews. ${ }^{25}$ These places always included the experience of past violence without the violence itself being present, either by reminding survivors of particular, violent events that happened in particular places, or by reminding them that the absence of family members, friends, and others was a result of violence.

Even when the specter of violence drove many survivors away from home, home remained an anchor. In a 2005 interview, Gol'braikh shared that every year he used to visit Beshankovichy, the family that sheltered him, and the gravesite, but had not been there since 1998. Health issues had made it difficult to travel, and during his last trip he was not even able to visit the grave to pay his respects to his mother and sisters because he was unable to climb the hill leading toward the killing site.

Gol'braikh was one of perhaps four survivors of the execution; none of them returned to live in Beshankovichy. A few other Jews who had been

19. Gol'braikh, interview, 2002; see also Franziska Exeler, "What Did You Do during the War? Personal Responses to the Aftermath of Nazi Occupation," Kritika: Explorations in Russian and Eurasian History 17, no. 4 (Fall 2016): 817.

20. Tim Cole, Holocaust Landscapes (London, 2016), 2.

21. Pollack, Kontaminierte Landschaften, 61.

22. Rita Kazhdan, interview, St. Petersburg, May 12, 2005.

23. On spectrality, the capacity of a place to enchant and haunt, see Derek P. McCormack, "Remotely Sensing Affective Afterlives: The Spectral Geographies of Material Remains," Annals of the Association of American Geographers 100, vol. 3 (2010): 642. The associated notion of haunting, of an affective impact of historical legacies, is most fully developed in Jacques Derrida, "Apparition of the Inapparent: The Phenomenological "Conjuring Trick," in his Specters of Marx: The State of the Debt, the Work of Mourning and the New International, eds. Bernd Magnus and Stephen Cullenberg, trans. Peggy Kamuf (New York, 1994), 169ff.

24. Gol' braikh, interview, 2001.

25. On haunting, see Avery F. Gordon, Ghostly Matters: Haunting and the Sociological Imagination (Minneapolis, 1997), esp. 7f. 
evacuated or had fought in the ranks of the Soviet Army returned to the town after the war. Over the decades however, the Jewish population in this former shtetl had steadily declined: in 1960, there were 125 Jews in Beshankovichy; by 1989, 26 remained, equaling $0.3 \%$ of the local population. ${ }^{26}$ In summer 2016, only two Jews, elderly women, lived in Beshankovichy.

The absence of Jewish survivors means that the bulk of postwar testimonies of Jews who lived through the German occupation in Beshankovichy and many other Belarusian towns and villages were given from afar, since the few survivors of mass killings often did not return. ${ }^{27}$ Testimony on site, in contrast, would be given by non-Jews, that is, by residents who looked on, worked within German institutions, or helped to identify, round up, and shoot their Jewish neighbors. The construction of local memory, in other words, relied on a particular perspective and likely omitted important parts.

Secondly, Gol'braikh's inability to visit Beshankovichy, as one of the last survivors of the massacre, causes alarm: who will visit the grave, if not the relatives of those who were killed? Will its remote location push the lives and deaths of at least 1,000 local Jews into complete oblivion? What will that absence do to the memory of the Holocaust, but also to the memory of Jewish life in Beshankovichy? After all, the grave is, at this point, one of only two visible markers of a past Jewish presence in the town; the other marker is the Jewish cemetery. There are no further traces of Jewish life before and during the war. The three synagogues that had survived or were rebuilt after a massive fire that nearly destroyed the town in 1922 were closed in the 1930 s. $^{28}$ Two of the buildings and many homes of Jewish families burned down during the war. The former Jewish school is now used by the local police, and the building's past is known only to insiders. Thus, we need stories such as Gol'braikh's to understand the significance of the existence, but also of the destruction and absence, of places and sites such as buildings, roads, rivers, meadows, and forests. Otherwise, a significant part of local history is being pushed into oblivion. Only stories can keep them alive.

Spatial relationships-of distance, of movement away and back and forth, of proximity and integration versus remoteness and absence-provide the scaffolding for these stories and reflect central historical trends and events. Space is deeply inscribed into what we can know, into the portrayals of these historical experiences and of how they are remembered or commemorated, yet it has often been neglected as a central dimension of analysis. ${ }^{29}$ Oral histories and other forms of testimony, together with a variety of other sources,

26. Gosudarstvennyi Arkhiv Vitebskoi Oblasti (hereafter GAVO), f. 1974, o. 11, d. 4 (Statistical data, Executive Committee Beshankovichy); A. Podlipskii, "Byli ... est' . . . i budem?," Mishpokha 2 (1996): 125-26.

27. On the impact of distance on survivor testimony, see Hannah Pollin-Galay, "The Holocaust is a Foreign Country: Comparing Representations of Place in Lithuanian Jewish Testimony," Dapim: Studies on the Holocaust 27, no. 1 (2013): 26-39.

28. Konstantin Karpekin, "Arkhivnye dokumenty o Beshenkovichskikh sinagogakh," Moe Mestechko-My Shtetl at http://shtetle.com/Shtetls/beshenkovichi/beshenkovichi_ syn.html (last accessed February 15, 2018).

29. Alberto Giordano, Anne Kelly Knowles, and Tim Cole, "Geographies of the Holocaust," in Anne Kelly Knowles, Tim Cole, and Alberto Giordano, eds., Geographies of the Holocaust (Bloomington, 2014), 8. 
help us to overcome this failure and uncover and understand particular and meaningful spatial relationships. This allows us to develop a sophisticated and complex portrayal of the relationship between history and memory by following narrators' stories in their quest to offer (oral) historical geographies. ${ }^{30}$ At the same time, attention to space and place enhances our understanding of people's lives, of the sites, things, and people that mattered to them and, in this case, were lost as a result of genocide. For survivors, hometowns such as Beshankovichy often figure as manifestations of this annihilation. ${ }^{31}$ Exploring places and spatial relationships between history, memory, and commemoration provides insights into the genocide's aftermath and the way in which local communities deal with the eradication of a part of their own history.

A brief portrayal of the sites of both the existence and destruction of Beshankovichy's Jewish community and the spatial relationships between them illustrate the meaning and omissions of current forms of commemoration. Such an account foregrounds the incongruence of the place of historical experience on the one hand, and current forms of remembering and commemoration on the other, while highlighting the impact of the Holocaust in Belarus, part of the former Pale of Jewish Settlement.

\section{Jewish life in Beshankovichy, 1630-1941}

Founded in the fifteenth century and given town privileges in 1630, Beshankovichy quickly developed into a lively and economically active town, with a major wave of Jewish settlement in the early seventeenth century. ${ }^{32}$ Over the years, the place came to house hundreds of tailors, cabinetmakers, shoemakers, blacksmiths, tanners, tinsmiths, and other artisans. By 1897, more than $71.9 \%$ of the town's population was Jewish. ${ }^{33}$ Following the October Revolution in 1917, many Jews left Beshankovichy and the share of Jews in the local population declined to about $16 \%$ in $1939 .{ }^{34}$ Nonetheless, a local resident recently described prewar Beshankovichy as "about 80\% Jewish" in the immediate prewar period. ${ }^{35}$ This perception indicates that Jewish culture was very much present and continued to play an important role in local life: nonJewish residents spoke Yiddish, and students of Belarusian or Russian nationality enrolled in the Jewish seven-year school. ${ }^{36}$ Jews lived all over town, a substantial number of them in Strelka, a section of town located on the right side of the river. ${ }^{37}$ In sum, while the infrastructure of what had once created

30. Tim Cole, “(Re)Placing the Past: Spatial Strategies of Retelling Difficult Stories,” The Oral History Review 42, no. 1 (Winter/Spring 2015): 49.

31. See Pollin-Galay, "The Holocaust is a Foreign Country," 38-39.

32. Iudovin, "Legendy i byli," 60-61.

33. Ibid., 61.

34. Podlipskii, “Byli ... est' . . . i budem?,” 26.

35. Lidia Pavlovna Komzykova, interview, Beshankovichy, June 5, 2016.

36. Ibid. 7; Gol' braikh, interview, 2001; Tatiana V., Yahad-In Unum Archives (hereafter YIU), Witness No. 507B; interview, Beshankovichy, June 22, 2011.

37. Vera S., YIU 504B; interview, Beshankovichy, June 22, 2011; Tatiana V., YIU 507B; see also Iakov Iudovin, "Parom," Zametki po evreiskoi istorii, setevoi zhurnal evreiskoi 
one of the shtetlakh had been dismantled by the late 1930s, Jews were very much integrated into the town and Jewish culture had a significant impact on non-Jewish residents.

All of that changed in June 1941, when German troops advanced through Belarus and defeated the Soviet troops. Within days, German forces occupied the area and established the rule of the Rear Area, Army Group Center in July 1941. (The 34 $4^{\text {th }}$ Army Corps of the $3^{\text {rd }}$ Panzer Group seized the left bank of the Dvina, $5^{\text {th }}$ Army Corps of the $9^{\text {th }}$ Infantry Army the right.) Relationships between individuals changed drastically, with residents scrambling to find safety or amass material possessions that could be useful to survive a war. Iakov Genin, then sixteen years old, described his and several other Jewish adolescents' attempts to flee the area and the way in which they were treated by "locals with a particular attitude": when Germans caught up with the group and turned them back toward Beshankovichy, these local "hooligans took away our little suitcases, our coats-basically, they robbed us." ${ }^{38}$ Genin's narrative suggests that he assumes antisemitic prejudice ("particular attitude") as the driving force for the adolescents' (podrostki) behavior. Genin also recalls that, following the Germans' example, local residents took to calling their Jewish neighbors "iude" (Jude, German for Jew), which clearly delineates a break from friendly prewar relations and supports Genin's assessment. Recent scholarship suggests that antisemitic stereotypes and prejudices, including imagery of Jews as being cheaters, lazy, or only interested in commercial rather than productive activity, had a powerful influence on local populations in the 1930s and 1940s Soviet Union. ${ }^{39}$ The availability of these attitudes despite the Sovietization campaigns of the 1920s and 1930s and locals' knowledge of their neighbors' hard work throughout the prewar period, provided fertile ground for the stigmatization and exclusion propagated and implemented by German authorities.

War and the occupation regime disrupted this apparently fragile community and inserted violence into local relationships in other ways, too. A camp for captured Soviet soldiers was established in the center of town; residents witnessed how the prisoners were horribly abused and forced to work; they also witnessed executions of POWs and civilians accused of sabotage or aiding partisans throughout the occupation period. ${ }^{40}$ Simultaneously, local

istorii, traditsii, kul'tury 3 (150), 2012; http://berkovich-zametki.com/2012/Zametki/Nomer3/Judovin1.php (last accessed October 26, 2016).

38. Iakov Markovich Genin, interviewed by Daniil Romanovsky, United States Holocaust Memorial Museum (hereafter USHMM) Archives, RG 68.186, Daniil Romanovsky collection, b. 1, f. 1, p. 1. Romanovsky interviewed survivors and eyewitnesses of the Nazi genocide in Russia, Belarus, and Ukraine in the late 1980s-early 1990s. Concrete dates are given only in some cases.

39. Aliaksandr Smalianchuk, "Tragedyia khalakostu i ie prychyny ŭ vusnykh uspaminakh Belarusaŭ," in Homo Historicus 2016: Gadavik antrapalagichnai gistorii, ed. Aliaksandr Smalianchuk (Vilnius, 2016), 177-78, at http://palityka.org/en/2016/04/homohistoricus-2016/ (last accessed February 19, 2018).

40. Genin, USHMM, RG 68.186, b. 1, f. 1, p. 25; Gol'braikh, interview, 2002; USHMM 22.002, f. 7021, 0. 84, d. 1, 1.76-77ob. (Materialy o zlodeianiakh nemetsko-fashistskikh zakhvatchikov nad sovetskimi grazhdanami i voennoplennami Beshenkovicheskogo raiona, Vitebskoi oblasti), (Witness statements of Petr Antonovich Bornko and Iakov Semenovich Dimenko); Liudmilia Petrovna Mikhailovskaia, interview, Beshankovichy, June 5, 2016. 
residents began to participate in violence and abuse: Ivan Ivitskiy, a former teacher, was at the helm of the local police headquartered in Marienfeldt, a so-called German colony in town..$^{41}$ Vladimir Tserkovskii, also a teacher, became the village elder (starosta) and not only helped enforce German laws and rules, but also personally humiliated Jews..$^{42}$ This and a substantial number of residents' "work for the Germans" must have been a deeply humiliating and upsetting experience for the local Jewish community, especially when this engagement concretely targeted them. Since many homes had burned down during the severe fighting in July 1941, many locals moved in with relatives when possible. ${ }^{43}$ Others, mostly Jews, were kicked out of their homes to make room for members of the police or for German officers and personnel..$^{44}$

All local Jews, mostly women, children, and the elderly, had to resettle into a limited number of homes in the area of ulitsa Svoboda, an area that effectively constituted a ghetto. While this relocation meant that the ghetto inhabitants remained close to their previous homes (and thus did not experience the rupture that a deportation to a concentration or extermination camp would have entailed), the displacement through ghettoization was an experience that shattered existing networks and livelihoods, limiting residents' access to food, wood to heating their houses, and other necessities. Moreover, it extracted them from the local community. Given the fact that Jewish community institutions had been destroyed through secularization and Sovietization campaigns in the 1920s and 1930s, ghettoization isolated Jews from existing connections with non-Jews and networks of mutual support and called on them to develop new, internal networks, or to rely on themselves. Ghettos in Soviet territories thus acquired a different meaning than those in Poland, especially in the area that was not annexed by the Soviet Union in 1939, where Jewish communal life had continued during the 1930s and had the potential to provide opportunities for mutual assistance, at least in the beginning..$^{45}$

In Beshankovichy, often five to six families had to share one house, which they had to mark with a large Star of David. On the other side of the river, in Strelka, several Jewish families were crammed into one house, the home of the Iudovin family. The ghetto was not fenced in, but heavily guarded, which turned it into one of the so-called open ghettos that were regularly used in

41. Genin, USHMM, RG 68.186, b. 1, f. 1, p. 2.

42. Ibid., p. 24; Efim Iudovin, "Bez sroka davnosti," Moe Mestechko-My Shtetl at http://shtetle.com/Shtetls/beshenkovichi/udovin.html (last accessed February 15, 2018). See also the discussion of local police and others' participation in identifying, humiliating, and exploiting Jews in Leonid Rein, The Kings and the Pawns: Collaboration in Byelorussia during World War II (New York, 2011), 253-77.

43. Tatiana V., YIU 507B.

44. Genin, USHMM, RG 68.186, b. 1, f. 1, p. 1-2; Raisa Khatskelevna Gurevich, interviewed by Daniil Romanovsky, USHMM, RG 68.186, b. 1, f. 1, p. 9. Vera S., YIU 504B; Iudovin, "Bez sroka davnosti”; Romanovsky, "Beshankovichy,” 1648.

45. See Deborah Dwork and Robert Jan van Pelt, Holocaust: A History (New York, 2002), 217, who argue that "the inhabitants of east European ghettos were connected to the history of the place in which they were now compelled to live. These streets, synagogues, and markets had grown over centuries to meet the Jewish community's needs; they now suggested that life could go on." 
German-occupied Soviet territories, a practice that reflected the often very short duration of ghettoization in preparation for mass murder. ${ }^{46}$ Venturing into town, Jews were required to wear round, yellow patches on their clothes, but they were not allowed to leave the ghetto at nighttime or to leave town. Nevertheless, German SS and local police tormented the ghetto inhabitants, breaking into homes to abuse and rape women or steal property. ${ }^{47}$ Many ghetto dwellers used the porous boundary of the ghetto to knock on their neighbors' doors to ask for potatoes or husks of grain or combed through people's vegetable gardens in the hope that some carrot or beet had been overlooked during the harvest. Others were lucky to receive visits from nonJewish neighbors who brought food, sometimes in exchange for clothes or other goods. Gol'braikh's family was fortunate because they stayed in their own home, and even though space became constricted when several other families moved in, "we could at least heat our little hut" with wood that they had stored for the winter. ${ }^{48}$

All of the approximately 100-150 Jewish men who had not been drafted into the army, together with women such as Leonid Gol'braikh's mother, had to report for forced labor every morning, during which they crushed bricks to cover roads and felled trees in parks and forests; "when there was no real work to do, the Germans made us dig holes or drag stones from one place to another." ${ }^{\prime 49}$ The workers received some food, though not nearly enough to sustain themselves or their families, who received nothing. Throughout summer and fall 1941, individual Jews-among them, the glazier and the watchmakerwere shot for no apparent reason, increasing the sense of doom among those living in the ghetto. ${ }^{50}$ Essentially, Iakov Genin says, they lived "like a hunted

46. On the so-called open ghettos, see Al'bert Kaganovich, "Voprosy i zadachi issledovania mest prinuditel'nogo soderzhania evreev na territorii Belarusi v 1941-1944gg.," in Aktual'nye voprosy izuchenia kholokosta na territorii Belarusi v gody nemetsko-fashistskoi okkupatsii: Sbornik nauchnykh rabot, ed. Ia. Z. Basin (Minsk, 2005), electronic document, http://www.jewniverse.ru/RED/Kaganovich/Belarusia\%5B2\%5D.htm (last accessed February 15, 2018); Martin Dean, "Life and Death in the 'Gray Zone' of Jewish Ghettos in Nazi-Occupied Europe: The Unknown, the Ambiguous, and the Disappeared,” in Jonathan Petropoulos and John K. Roth, eds., Gray Zones: Ambiguity and Compromise in the Holocaust and Its Aftermath (New York, 2005), 205-21; Martin Dean, "Eastern Belorussian Region," in Encyclopedia of Camps and Ghettos, 1933-1945, Vol. II: Ghettos in German-Occupied Eastern Europe, 1640.

47. On such transgressions as a regular practice in ghettos in the German-occupied Soviet territories, see Rein, Kings and Pawns, 274.

48. Gol'braikh, interview, 2005.

49. Genin, USHMM, RG 68.186, b. 1, f. 1, p. 2.

50. For details on the treatment and ghettoization of Beshankovichy's Jews, see Gol'braikh, interviews, 2001 and 2002; Genin, USHMM, RG 68.186, b. 1, f. 1, p. 1-2; Tatiana V., YIU 507B; Vera S., YIU 504B; Mikhailovskaia, interview, 2016; Genia Nosonovna Supina, interview, Beshankovichy, June 4, 2016; Iudovin, "Bez sroka davnosti”; Maria Voronkova, "Kholokost v Beshenkovichakh: Svidetel'stva," Moe Mestechko-My Shtetl at http://shtetle.com/Shtetls/beshenkovichi/beshenkovichi.html (last accessed February 15, 2018); Iakov Rukhman, "Dva goda ia byla devochkoi," Moe Mestechko-My Shtetl at http://shtetle.com/Shtetls/beshenkovichi/ruhman.html (last accessed February 15, 2018); Moisei Mitsengendler, "Po doroge k paromu," Mestechko-My Shtetl. http://shtetle.com/Shtetls/beshenkovichi/micengendler.html (last accessed February 15, 2018). 
wolf, everybody shuns you, nobody offers help: the people are afraid, police taunts you, and the Germans hate you." 51

Whereas Jews were outcasts and severely limited in their movement and ability to survive, non-Jewish residents were not restricted in the same way. Some report that they preferred to stay home as much as possible so as to avoid capture for forced labor in Germany and other forms of abuse, yet a semblance of normalcy distinguished their lives from their Jewish neighbors. ${ }^{52}$

\section{The Killing}

These contrasting experiences come into view most drastically in the memory of one of the residents. Klara S., who was eleven at the time, remembers that she was sledding at the riverbanks with a friend when they noticed a large group of people being lead across the ice on February 11, 1942. Quickly they found out that these were local Jews, "probably" on their way to the execution..$^{53}$ That day, up to 1,000 Jews were forced from their homes in the morning hours without warning and taken to an execution site. ${ }^{54}$ Most, like Iakov Genin's neighbor, realized only when the round up was underway what was about to happen: he burst into Genin's house and yelled, in Yiddish: "Ratevet zikh, m'khapt yidn tsu shisn!" (Save yourself, they're taking Jews to be shot!) ${ }^{55}$ Those who did not manage to hide, primarily women, children, and the elderly, were chased to the bazaar and then led through town for everyone to see. Jews who were at work that day were taken straight from their workplace. Members of the local police, who were instrumental in identifying Jewish residents, and Einsatzkommando 9 guarded the crowd on their journey across the river and into the forest. ${ }^{56}$ Notably, non-Jewish witnesses admit that locals participated in rounding up the Jews that day and throughout the occupation period, though none of them is willing to identify just who these participants were. Several people who had been forced into the column were shot on the spot or along the way, either because they tried to run away or were unable to move fast enough. ${ }^{57}$

For good reason, locals who suspected or knew what was happening stayed away or locked themselves in their homes: an older Belarusian man, possibly because he was wearing similar clothes to what Germans thought was typical for Jewish men and sporting a long beard, was pushed into the column. Frightened, Liudmila Mikhailovskaia's grandfather managed to find

51. Genin, USHMM, RG 68.186, b. 1, f. 1, p. 3.

52. Komzykova, interview, 2016.

53. Klara S., Yahad-In Unum Archive, Witness No. 505B, interview, Beshankovichy, June 22, 2011.

54. Iakov Genin remembers that all Jews had to register and 967 Jews were accounted for two months before the execution, Genin, USHMM, RG 68.186, b. 1, f. 1, p. 26.

55. Ibid., p. 3.

56. Gurevich, USHMM, RG 68.186, b. 1, f. 1, p. 11; Boltovich, interviewed by Daniil Romanovsky, USHMM, RG 68.186, b. 1, f. 1, p. 20. On local police supporting the roundup of Jews for executions, see Rein, Kings and Pawns, 268-69.

57. USHMM 22.002, f. 7021, 0. 84, d. 1, 1.76-77ob (Materials on German atrocities against Prisoners of War and civilians in the district of Beshankovichy); Gol'braikh, interview, 2001; Tatiana V., YIU 507B; Voronkova, “Kholokost v Beshenkovichakh;” Iudovin, "Parom.” 
a policeman who recognized him and let him go not far from the shooting site. ${ }^{58}$ Others had been ordered to report in the morning with sleds. They were asked to collect the dead bodies left behind. ${ }^{59}$ Still others made themselves accomplices to mass murder and dragged Jews out of hiding places to deliver them to the local police or Germans involved in the roundup. Efim Iudovin's cousin Riva, for instance, was able to hide in the basement of a neighbor's house, but the former biology teacher, Konstantin Tserkovskii, pulled her out and handed her over to the guards of the column; local Stepan Gudian similarly dragged out a woman from a hiding place and delivered her to the collection point. ${ }^{60}$

Thirty prisoners of war interned in the local camp had been forced to dig two large pits in the forest north of Strelka the day before. Presumably, the Germans chose the site to be within walking distance from town, but far enough removed to avoid too many witnesses. ${ }^{61}$ Upon arrival there, the Jews had to undress down to their underwear and were shot in small groups; small children and the weak or ill and elderly were thrown alive into the pit and killed by a hail of bullets. ${ }^{62}$ Residents of Strelka and Beshankovichy heard the shots all day. ${ }^{63}$ Local residents sorted the clothing left behind by the Jewish victims. ${ }^{64}$ The gravesite was cordoned off for a few days, although some residents shared that the surface of the soil continued to move for several days. It is likely that policemen spread this information. ${ }^{65}$ In March, the site was covered with carbolic acid when, presumably with the onset of the thaw, the smell of decomposition began to spread. ${ }^{66}$

The day after the execution, clothes left behind by the murdered Jews were auctioned off among locals in the schoolyard, a practice that was widespread in German-occupied European societies. ${ }^{67}$ The now abandoned

58. Mikhailovskaia, interview, 2016.

59. Roman Konstantinovich Shnitko, interviewed by Daniil Romanovsky, USHMM, RG 68.186, b. 1, f. 1, p. 18; Komzykova, interview, 2016.

60. Iudovin, "Bez sroka."

61. Rein, Kings and Pawns, 271.

62. Voronkova, “Kholokost v Beshenkovichakh;” Iudovin, “Bez sroka.” One survivor remembers that in 1958, when a monument was erected at the site, Russian bullet casings and a piece of a Russian bayonet were found below the surface, suggesting that local police actively participated in the shooting. Lev Isaakovich Iudovin, USHMM, RG 68.186, b. 1, f. 1, p. 29.

63. Tatiana V., YIU 507B; Valentina Vladimirovna Beresten', interview, Beshankovichy, June 5, 2016.

64. Gol'braikh, interview, 2001.

65.KlaraS.,YIU505B; TatianaV.,YIU507B; Voronkova, “KholokostvBeshenkovichakh.” 66. Shnitko, USHMM, RG 68.186, b. 1, f. 1, p. 19.

67. On Beshankovichy, see Gurevich, USHMM, RG 68.186, b. 1, f. 1, p. 12. For more on the local population or policemen robbing or profiting from Jewish property in the occupied Soviet territories, see Daniel Romanovsky, "The Holocaust in the Eyes of Homo Sovieticus: A Survey Based on Northeastern Belorussia and Northwestern Russia," Holocaust and Genocide Studies 13, no. 3 (Winter 1999), 371-73; Martin Dean, "Jewish Property Seized in the Occupied Soviet Union in 1941 and 1942: The Records of the Reichshauptkasse Beutestelle," Holocaust and Genocide Studies 14, no. 9 (Spring 2000), 91; Yitzhak Arad, "Plunder of Jewish Property in the Nazi-Occupied Areas of the Soviet Union," Yad Vashem Studies 29 (2001): 109-48; Martin Dean, Robbing the Jews: The Confiscation of Jewish Property in the Holocaust, 1933-1945 (Cambridge, 2008), 173-221; Yitzhak Arad, 
homes of Jewish families were occupied by locals, possibly on their own initiative, possibly after the local administration allocated the houses to people who had lost their homes in the summer of $1941 .{ }^{68}$ Many of these houses were destroyed later, when Soviet and German troops fought over the area. During their retreat, the Germans doused the surface of the graves with gasoline and set it on fire, attempting to erase the remaining traces of the graves. ${ }^{69}$ Most likely, this attempt to cover up took place as part of the German-led "Aktion 1005." During this operation, Soviet POWs, ghetto inmates, and locals were driven to mass execution sites, where they had to unearth the mass graves, remove and then burn the corpses of Jews, Soviet soldiers, and others who had been killed earlier. Ashes were strewn about the surrounding areas or dumped in rivers. ${ }^{70}$ In the east of what is now Belarus, these exhumations and subsequent burnings took place in late fall and winter $1943 .{ }^{71}$

In spring 1944, Beshankovichy, like much of Vitebsk oblast and other areas of Belarus, was the site of intense fighting, with German troops viciously trying to fend off the Soviet advance and attacking partisan forces active in the area. Local residents were used to uncover mines placed by partisans or others: they had to walk along roads before German troops would march or drive on them; many were injured or died when they triggered explosives. ${ }^{72}$ Local police, it appears, were even more brutal and "set everything on fire during the retreat," helping to create a situation in which many locals left the town and sought shelter in the surrounding forests. ${ }^{73}$

Beshankovichy was liberated from the German occupation by June 26, 1944. By then, the German occupation regime had decimated the local population, Jewish and non-Jewish alike: 10,000 residents of the Beshankovichy raion (district) had been killed, about 5,000 in the town of Beshankovichy alone. ${ }^{74}$ German rule had also laid bare frictions and divisions within the Soviet population, making the killing of up to 2,900 Jews in the Beshankovichy district (the town itself and several surrounding sel'sovety [rural districts]),

The Holocaust in the Soviet Union (Lincoln, 2009), 403-10; Desbois, Holocaust by Bullets, 97; Rein, Kings and Pawns, 273-76. On Poland, see Jan Tomasz Gross with Irena Grudzinska Gross, Golden Harvest: Events at the Periphery of the Holocaust (New York, 2012); an overview of various European societies' involvement in appropriating Jewish possessions and properties, see Avi Beker, ed., The Plunder of Jewish Property during the Holocaust: Confronting European History (New York, 2001).

68. Vera Ivanovna Zhukova, interviewed by Daniil Romanovsky, USHMM, RG 68.186, b. 1, f. 1, p. 21; Vera S., YIU 504B; Tatiana V., YIU 507B. See Gross and Grudzinska Gross, Golden Harvest, 44, for the run on formerly Jewish apartments in Poland after their inhabitants had been displaced, deported, or murdered.

69. Iudovin, "Bez sroka."

70. Gerlach, Kalkulierte Morde, 773.

71. Leonid Smilovitskii, “'Operatsia 1005’ v Belarusi,” in Homo Historicus 2016: Gadavik antrapalagichnai gistorii, ed. Aliaksandr Smalianchuk (Vilnius, 2016), 148, at http:// palityka.org/en/2016/04/homo-historicus-2016/ (last accessed February 19, 2018).

72. Mikhailovskaia, interview, 2016; Komzykova, interview, 2016.

73. Ibid.

74. USHMM 22.002, f. 7021, o. 84, d.1, 1. 3. 
possible because locals were willing to help identify, round up, and possibly even shoot them. ${ }^{75}$

\section{Beshankovichy after the War, Jewish Life in Postwar Beshankovichy}

The Soviet Extraordinary State Commission for Ascertaining and Investigating Crimes Perpetrated by the German-Fascist Invaders and their Accomplices (ChGK) recorded two large gravesites for the murder of Beshankovichy's Jews, though the location of only one of them is known among locals at this time. ${ }^{76}$ Like many other graves, such as those of soldiers who died in the fighting, or of POWs and civilians, the mass grave in Beshankovichy remained unmarked for several years. After Stalin's death, individuals and state authorities began to identify and mark these wartime graves..$^{77}$ Lazar Mitsengendler, one of the Jews who had returned to Beshankovichy from evacuation, took it upon himself to collect donations from survivors and relatives of those killed to pay for a memorial on the grave site. In summer 1958, a memorial stone roughly resembling an obelisk was placed on one grave site; it listed 1,068 Jewish victims, a number that presumably included a group of Jewish professionals who had been spared in February 1942 but were killed later that year, and Jews from surrounding villages such as Chashniki, Senno, and Ulla who had been interned in the Beshankovichy ghetto as well. ${ }^{78}$ Mitsengendler's home became a destination for many Jews who were eager to visit the grave. He taught his daughter-in-law to prepare Jewish dishes for himself and his guests and took on the role of a memory keeper. ${ }^{79}$

Almost all Jewish survivors with whom I was able to speak, owned a photo of the memorial's dedication. The establishment of the memorial marked the otherwise invisible gravesite and additionally protected the area from further defacement. The site of mass murder thus became a concrete and physical site of commemoration, functioning in a way similar to the lieux de mémoire that

75. Ibid. For more expansive portrayals of the collaboration or participation of local residents in what is now the Republic of Belarus, see Martin Dean, Collaboration in the Holocaust: Crimes of the Local Police in Belorussia and Ukraine, 1941-1944 (New York, 2000); Rein, Kings and Pawns; Exeler, "What Did You Do during the War."

76. NARB, f. 845, o. 1, d. 5, 1. 1 (Report of Vitebsk commission to investigate German atrocities in Vitebsk and oblast' Vitebsk); USHMM 22.002, f. 7021, o. 84, d. 1, 1. 17. Note that the two documents list different sizes for the graves. See also Gol'braikh, interview, 2005; Stanislav Leonenko in Beresten', interview, 2016; S. Leonenko and A. Trubetskoi, interview, Beshankovichy, June 5, 2016.

77. On the struggle to erect memorials on Jewish mass graves in the immediate postwar period and the following shift, see Mordechai Altshuler, "Jewish Holocaust Commemoration Activity in the USSR under Stalin,” Yad Vashem Studies 30 (2002): 271-96; Arkadi Zeltser, Memory in the Monuments: Jewish Soviet Identities and the Holocaust (Yad Vashem, forthcoming).

78. Genin, USHMM, RG 68.186, b.1, f. 1, p. 3, 26; Beresten', interview, 2016; Voronkova, "Kholokost v Beshenkovichakh"; Galina Maizel, "My rodom iz Beshenkovichei i Slutska," Moe Mestechko-My Shtetl at http://shtetle.com/Shtetls/beshenkovichi/mayzel.html (last accessed February 15, 2018). NB: ChGK lists 2,900 Jewish victims to the mass murder. The origin of this number is somewhat murky.

79. Beresten', interview, 2016. 
Pierre Nora identifies in his analysis of the spatial constitution of memory. ${ }^{80}$ In addition, the site acquired symbolic value. Not only is the number of 1,068 a stand-in for the actual number of victims-many witnesses and the documents of the ChGK report that 800 victims were killed on February 11, 1942, though we also know of later shootings-and for victims of killings elsewhere, in unidentified places. ${ }^{81}$ The memorial is thus a memorial for all Jews from the area who were murdered during the German occupation and commemorates the community that was annihilated. It was transformed into a site at which the remaining Jews with roots in Beshankovichy could come together and figured as something akin to a sacred center, the locus of Jewish community in Beshankovichy after the community as such ceased to exist. ${ }^{82}$

In 1956, two years before the memorial in the forest was erected, a monument was placed behind the local school on the site of a mass grave for 142 Soviet soldiers who died during the fighting in June/July 1944, including four who were honored as Heroes of the Soviet Union. Kurgan Slavy, a mound to honor Soviet soldiers and partisans, was dedicated near the main road of Beshankovichy in 1966, and a monument to commemorate members of the local Komsomol was established in 1970 in a park located centrally in the town, across from the building of the Ispol'nitelnyi Komitet (local executive committee). Local residents, workers, and partisan aides were honored in 1966 with a statue near the main road close to the town limit that displays a man sporting a rifle and a young girl kneeling at his feet, as well as a symbolic gravestone in $2007 .{ }^{83} \mathrm{All}$ of these monuments are located in the center of town or close by and are sites of annual ceremonies (see Figure 2).

How does the surviving community relate to the various monuments and memorials? One resident explains: "I go on my own when there is a ceremony at the mass grave [of Soviet heroes], at the Lenin statue, for the komsomoltsy. This is just common sense; there are no special summons. This is simply my duty, to honor my ancestors." ${ }^{4}$ When local residents were asked whether they visited the grave site "za Dvinoi," the answer typically is negative. Several claimed that they never went there because it is too far. ${ }^{85}$ One woman evoked the specter of violence associated with the site to explain why she avoided the

80. Pierre Nora, "Between Memory and History: Les Lieux de Mémoire," Representations, no. 26, Special issue on Memory and Counter-Memory (Spring 1989): 7-25. See also Jay Winter, Sites of Memory, Sites of Mourning: The Great War in European Cultural History (Cambridge, Mass., 1995); Steven Hoelscher and Derek H. Alderman, "Memory and Place: Geographies of a Critical Relationship,” Social \& Cultural Geography 5, no. 3 (2004): 347-55.

81. See footnote 78 and Grigorii Vasil'evich Sheenok, interviewed by Daniil Romanovsky, USHMM, RG 68.186, b. 1, f. 1, p. 20; Vera Nikolaevna Pankevich, interviewed by Daniil Romanovsky, USHMM, RG 68.186, b. 1, f. 1, p. 23.

82. On the sacralization of memorial space, see Katharina Schramm, "Introduction: Landscapes of Violence: Memory and Sacred Space," History and Memory 23, no. 1 (Spring/Summer 2011), 7.

83. Beshenkovichskii Raionnyi Istoriko-Kraevedcheskii Muzei, Gosudarstvennoe uchrezhdenie "Beshenkovichskii raionnyi istoriko-kraevedcheskii muzei," "Gistorikakul'turnaia spadchyna beshankovitskaga raena,” http://beshenkovichi.museum.by/ node/42940 (last accessed February 15, 2018).

84. Aleksei Vasielevich Khriptenko, interview, Beshankovichy, June 4, 2016.

85. Mikhailovskaia, interview, 2016. 


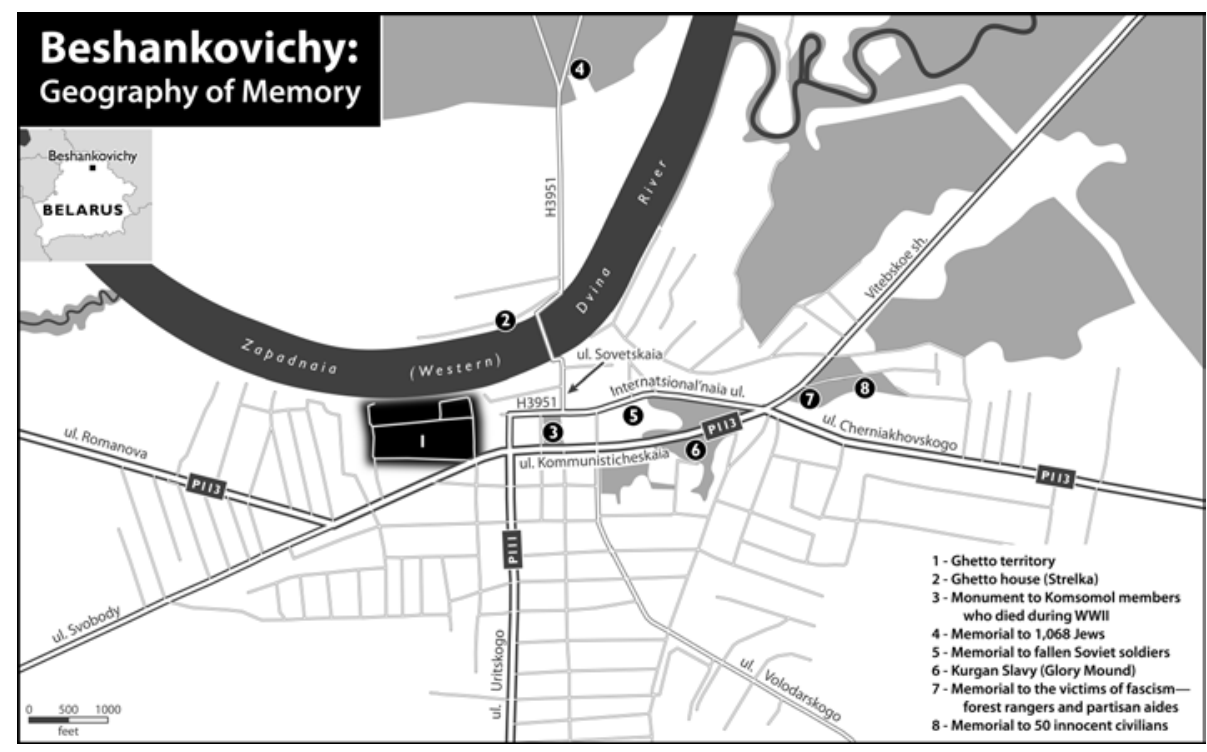

Figure 2. Beshankovichy: Geography of Memory. Map created by Alison DeGraff Ollivierre, Tombolo Maps \& Design. Copyright Anika Walke.

gravesite: "I never went to the grave, I was afraid. I was afraid of what these people had gone through." 86 Others (sometimes the same people) stated that they went there by accident when collecting berries or picking up bricks from the nearby brick factory. ${ }^{87}$ One woman recalled seeing the memorial when she and her family picnicked in the woods. ${ }^{88}$ The former local secretary of the Komsomol could not recall ever visiting the site with students, or that students would have gone there on their own. ${ }^{89}$ Perhaps, the woman suggested, there was no special effort to integrate the site into local commemorative practices, because Soviet internationalism prohibited singling out particular nationalities. ${ }^{90}$ Visiting the other monuments, in contrast, serves to "keep the memory of our ancestors alive, of those who fought and defended us against the genocide and against the Germans." ${ }^{11}$ The Jewish residents of Beshankovichy do not seem to belong to this community of ancestors.

The memorial in the forest has been vandalized several times since its dedication. Leonid Gol'braikh remembers stumbling over skulls, bones and pieces of clothing one year, shocked to discover that grave diggers had sought to find valuables in the ground. The search for "Jewish gold," not uncommon at Jewish mass graves in eastern Europe, operates on the basis of stereotypes that ascribe Jews uncommon wealth. ${ }^{92}$ It also draws on local residents' knowledge

86. Komzykova, interview, 2016.

87. Klara S., YIU 505B; Tatiana V., YIU 507B; Komzykova, interview, 2016.

88. Resident of Beshankovichy, informal conversation, June 5, 2016.

89. Valentina Kuprianovna Khriptenko, interview, Beshankovichy, June 4, 2016.

90. Ibid.

91. Aleksei Khriptenko, interview, 2016.

92. Gol'braikh, interview, 2001. On local residents' pillaging and digging for Jewish possessions at sites of mass murder, immediately after the killings or years later, see Gross 
about the process of round up that often included a moment of deception: the claim that Jews would be simply resettled and were encouraged to bring valuable possessions..$^{93}$

Apart from scavengers, visitors over the years have been limited to people like Gol'braikh, who have come to mourn and remember their close ones, and memory activists and members of the Belarusian Jewish community. In February 2016, thirteen women and men, mostly from out-of-town, gathered to commemorate the mass killing, in February 2018-eight. ${ }^{94}$ Stanislav Leonenko, who until recently was the head custodian at the local history museum, organizes groups of high school students to clean up the area around the obelisk twice a year. ${ }^{95}$ Such efforts have the potential to pass on knowledge about the Jewish past of Beshankovichy, though given the lack of institutional support, the memorial and the grave site-and alongside them, a central element of the local past-may just as likely remain at the margins of local consciousness. ${ }^{96}$

\section{Imaginative Geographies of Commemoration}

Belarusian society as a whole is caught up in often contradictory attempts to define the portrayal of the past, specifically that of World War II, which serves current political agendas (chiefly the construction of a national identity), yet also answers to the demands of various groups to include their experience in commemoration and historiography ${ }^{97}$ These attempts reflect the desire both to liberate the country from overbearing Soviet legacies that can be easily appropriated by Russian politicians and activists and to maintain familiar tropes that, for decades, have shaped the way people have come to know and commemorate the past. ${ }^{98}$ The endeavor to carefully redesign practices of war

and Grudzinska Gross, Golden Harvest, 11, 87; Finder and Cohen, "Memento Mori,” 56-57; Pollack, Kontaminierte Landschaften, 100.

93. On non-Jews' awareness of their Jewish neighbors' impending death as a moment when their property will be available for the taking, see Gross and Grudzinska Gross, Golden Harvest, 74-75.

94. "Brama lia starykh mogilak," Zaria March 15, 2016; see also https://www.facebook.com/groups/Beshankovichy.cemetery/permalink/763797623755380/ and https:// www.facebook.com/groups/beshenkovichi.cemetery/permalink/1206496882818783/ (Private sites).

95. Stanislav Leonenko, interview, Vitebsk, September 21, 2016; see also https:// www.facebook.com/permalink.php?story_fbid=367827273562263\&id=100010049796469 (Private site).

96. Since 2015, a group of volunteers hailing from St. Petersburg, Russia, has worked to clean up and restore the local Jewish cemetery. Plans for the future include the establishment of a Jewish cultural center to educate the local and visiting public about the Jewish past of the town and the region. The center is also meant to provide support for Jewish families from around the world who search for information about their ancestors, many of whom have already donated to the cause.

97. For a comprehensive analysis, see David R. Marples, “Our Glorious Past”: Lukashenka's Belarus and the Great Patriotic War (Stuttgart, 2014); Aleksei Bratochkin, "Kul'tura pamiati v Belarusi (1988-2016): Ot raskola k konservativnomu konsensusu?,” GEFTER, November 25, 2016, http://gefter.ru/archive/20174 (last accessed June 12, 2017).

98. See Imke Hansen, "Belarussische Identitäts- und Geschichtskonstruktionen im öffentlichen Raum,” in Regina Fritz, Carola Sachse, and Edgar Wolfrum, eds., Nationen 
memory include an effort to account for the war dead. Exhuming, reburying, and honoring fallen soldiers is official policy, and despite frequent administrative obstacles some progress is being made in this regard. Civilian victims-more specifically, Jews-remain on the margins of these attempts, however. Apart from prestige objects such as the new memorial complex on the site of the concentration camp and killing center Maly Trostenets near Minsk-where among the up to 206,500 victims were approximately 65,000 Jews originating from Minsk but also from Bohemia and Moravia, Austria, Germany, the Netherlands, and Poland-the systematic mass murder of Jews is hardly mentioned..$^{99}$ Prominent signs at the new memorial, for instance, fail to mention that the majority of the victims were Jewish. Rather, inscriptions encode the genocide as the "extermination of Minsk residents and residents of other Belarusian towns" and "civilians deported from Europe."

In general, most Belarusian towns and villages resemble Beshankovichy with regard to commemorative practices. Soviet war heroes, partisans, and others who are seen as representatives of the united struggle against the Germans are commemorated in prominent places. Murdered Jewish civilians remain invisible and local Jewish history disappears into oblivion-unless memory activists, often the offspring of local Jews, take it upon themselves to mark the place to sustain the memory of the local past, that is, to clean up the Jewish cemetery, mark buildings, and keep memorial sites in order.

Without such interventions, the placement of, and interaction with, war memorials and monuments remains tied and limited to what Edward Said once aptly called an "imaginative geography": a geographical space that pays "scant attention to the actuality of the geography [of historical experience] and its inhabitants" and rather reflects the fantasies and preoccupations of the creators of the space. ${ }^{100}$ Said referred to colonizers, and while I do not suggest that Soviet authorities operated in the same way (that would be a different debate), I find the concept of an imaginative geography useful. The memory of the Soviet struggle against the German occupation is displayed prominently-in or near the center of town-a placement that reflects the official state-sponsored portrayal of World War II. This portrayal continues to

und ihre Selbstbilder: Postdiktatorische Gesellschaften in Europa (Göttingen, 2008), esp. 234, 239, 244, 248.

99. The number of people killed in Maly Trostenets and the two connected execution sites in nearby Blagovshchina and Shashkova (which are seen as part of the camp), is still contested. A recent joint German-Belarusian research and exhibition project determined the number cited here after careful review of all available sources. The results confirm that Maly Trostenets was the largest extermination site in German-occupied Belarus for Jews, Prisoners of War, partisans, and other civilians. See V.D. Selemenev, V.I. Adamushko, A.E. Dolgovskii, eds., Trostenets: Tragedia narodov Evropy, pamiat' v Belarusi: Dokumenty i materialy (Minsk, 2016); and Amélie zu Eulenburg, Adam Kerpel-Fronius, and Uwe Neumärker, Vernichtungsort Malyj Trostenez: Geschichte und Erinnerung (Dortmund, 2016). See also Yad Vashem: The International Institute for Holocaust Research, Transports to Extinction-Shoah Holocaust Deportation Database, "Maly Trostenets, Extermination Camp, Belorussia (USSR)," http://db.yadvashem.org/deportation/place.html?language=e n\&itemId=9193290 (last accessed June 8, 2017).

100. Edward W. Said, “Invention, Memory, and Place,” Critical Inquiry26, No.2(Winter 2000), 181; Edward Said, Orientalism (New York, 1978), esp. 71. 
favor the military victory, achieved through the heroic, collective struggle of the unified Soviet population, and honors those who sacrificed their life in battle. ${ }^{101}$

Notably, all statues in Beshankovichy feature male figures-soldiers, partisans, men displaying physical prowess and readiness to combat-at the center. Two females, one in uniform, the other in civilian clothing, guard Kurgan Slavy, their poses signaling their mourning for the fighters commemorated with the memorial. Using gendered figures to represent particular aspects of history and memory is not unusual, but doing so tends to neglect or omit central aspects of historical experience. ${ }^{102}$ Limiting the representation of females to passive acts or mourning neglects the fact that about one million women assumed important functions within the Soviet military and the partisan movement, serving as snipers, pilots, nurses, and in other roles. Furthermore, the memorials distort the memory of local events. While unquestionably hundreds of Soviet soldiers and partisans died in battles in the region, most of the civilians who were killed during the occupation were women, children, and the elderly. In particular, this applies to Jewish residents. ${ }^{103}$ They had been left behind when evacuation efforts failed or were limited to functionaries and personnel of production facilities that were considered central for the war effort and when men were mobilized into the army or arrested and killed as potential resisters in the first weeks of the war. ${ }^{104}$

Neglecting the disproportionate suffering of civilians identified by gender and age-women, children, and elderly people-goes hand-in-hand with marginalizing the specific targeting of Jews and the Holocaust. The Jewish grave is

101. On the character of Soviet war monuments, especially their focus on heroic fighters and members of the military or partisans, see, among others, Sabine R. Arnold, Stalingrad im sowjetischen Gedächtnis: Kriegserinnerung und Geschichtsbild im totalitären Staat (Bochum, 1998); Natal'ia Konradova and Anna Ryleva, "Geroi i zhertvy. Memorialy Velikoi Otechestvennoi,” in Mikhail Gabovich, ed., Pamiat' o Voine 60 Let Spustia: Rossia, Germania, Evropa (Moscow, 2005), 262-81.

102. For critical analyses of gender roles structuring modes of commemoration and historical representation more broadly see, among others, Insa Eschebach, Sigrid Jacobeit, and Silke Wenk, eds., Gedächtnis und Geschlecht: Deutungsmuster in Darstellungen des nationalsozialistischen Genozids (Frankfurt-am-Main, 2002); and Anna Reading, The Social Inheritance of the Holocaust: Gender, Culture and Memory (New York, 2002).

103. Genin, USHMM, RG 68.186, b. 1, f. 1, p. 2; Gol'braikh, interview, 2001.

104. See also Christoph Dieckmann and Babette Quinkert, "Einleitung," in Dieckmann and Quinkert, eds., Im Ghetto, 1939-1945, 25. On the Soviet government's focus on the evacuation of industrial facilities and necessary workers and resulting limitations to evacuating civilians, especially the lack of efforts to save Jewish lives threatened by Nazi extermination policy, see Ben-Cion Pinchuk, "Was There a Soviet Policy for Evacuating the Jews? The Case of the Annexed Territories,” Slavic Review 39, no. 1 (Mar., 1980): 44-55; Ben-Cion Pinchuk, "Sovietisation and the Jewish Response to Nazi Policies of Mass Murder," in Norman Davies and Antony Polonsky, eds., Jews in Eastern Poland and the USSR, 1939-46 (Houndmills, 1991), 132-33; Mordechai Altshuler, "Escape and Evacuation of Soviet Jews at the Time of the Nazi Invasion: Policies and Realities," in Lucjan Dobroszycki and Jeffery S. Gurock, eds., The Holocaust in the Soviet Union: Studies and Sources on the Destruction of the Jews in the Nazi-occupied Territories of the USSR, 1941-45 (Armonk, 1993), 77-104. For the most recent and comprehensive portrayal of Soviet evacuation policy, see Rebecca Manley, To the Tashkent Station: Evacuation and Survival in the Soviet Union at War (Ithaca, 2009). 
removed from sight and not included in the local regime of commemorationas opposed to the memorials to Soviet soldiers, partisans, non-Jewish locals, or the graves of (often unknown) soldiers or partisans buried near the town that locals care for, a practice common in Belarus. ${ }^{105}$ The difference between the failure to include the memorial into local commemorative practices on the one hand, and targeted visits by grave robbers on the other, is striking and points toward a fraught relationship of local residents to their own communal history and to former members of the local community-local Jews.

The distance between grave and town is, of course, first and foremost a result of the mass murder itself that was led by German occupation authorities. As elsewhere, the killing site was likely not chosen randomly, but was based on the main perpetrators' careful consideration. ${ }^{106}$ Avoiding too many spectators may have been one, though the fact that locals are said to have sorted the clothing that the victims had to remove prior to the killing puts this motive somewhat into question. Rather, the ability to dig into the ground in sandy soil even during the winter months, which was available in the forest, may have played a role. ${ }^{107}$ In addition, the opportunity to deceive the victims on their last journey likely affected the choice: the road to the prepared pits leads toward Shumilino, a nearby village, and one witness suggests that people believed they were being taken there for further resettlement. ${ }^{108}$ Eventually, camouflaging the killing sites-by choosing somewhat remote sites for mass shootings, or planting trees around camps-was part and parcel of the German murder practice. ${ }^{109}$ The nameless dead ought to disappear forever, "vanish into the landscape," together with the pits in which they are thrown, so that nobody would be able to perform rituals of mourning and remembrance. ${ }^{110}$ This additional form of dehumanization indicates the genocidal intent-not only are living human beings destroyed, but also their memory. ${ }^{111}$ Hiding the crime indicates the desire to eradicate: to obfuscate and produce amnesia. ${ }^{112}$ One may therefore say that the remoteness of the mass grave explains its sidelining, both figural and literal, in Beshankovichy's forest. Similar patterns can be observed in and around other Belarusian, Ukrainian, Russian, and

105. Until today, especially older generations do so. "Especially when these were young men who fought far away from home and nobody else would do it, locals take care of their final resting place.” Stanislav Leonenko, interview, Beshankovichy, June 5, 2016.

106. Pollack, Kontaminierte Landschaften, 20.

107. Waitman Wade Beorn, "Walking in the Footsteps of the Vanished: Using Physical Landscapes to Understand Wehrmacht Participation in Einsatzgruppen Killings in Belarus," in Hilary Earl and Karl A. Schleunes, eds., Expanding Perspectives on the Holocaust in a Changing World (Evanston, 2014), 300-1.

108. Mikhailovskaia, interview, 2016.

109. For instance, trees were planted to cover up the death camp Sobibor; see Jan Piwonski in Shoah. Directed by Claude Lanzmann. London: British Broadcasting Corporation (BBC), 1985; cf. Erin McGlothlin, “Listening to the Perpetrators in Claude Lanzmann's Shoah," Colloquia Germanica 43, no. 3 (2010), 250.

110. Pollack, Kontaminierte Landschaften, 25.

111. David Patterson, "Death and Ghetto Death," in Eric J. Sterling, ed., Life in the Ghettos During the Holocaust (Syracuse, 2005), 162, 171; Pollack, Kontaminierte Landschaften, 28.

112. Robert Brinkley and Steven Youra, “Tracing Shoah,” in "Special Topic: The Status of Evidence," special issue, PMLA 111, no. 1 (January, 1996): 125. 
Lithuanian towns. And yet, I want to suggest that there is an additional layer of desired oblivion, though enabled by the geographical distance, that we ought to consider to understand the dynamics of local Holocaust memory.

"Alongside the memory of the victims disappears the memory of the perpetrators," and perhaps this is why local residents of Beshankovichy (and elsewhere) are not too eager to be reminded of the killing site on the other side of the river. ${ }^{113}$ The perpetrators included not only German forces, but also local residents who helped round up the Jews and who appropriated their clothes or homes, which means that to honor and remember the dead would also mean to face local participation in humiliation and killing, a task that Belarusian society as a whole is reluctant to undertake. ${ }^{114}$ In the early postwar years, some people who had worked for the German occupation regime in some capacity were excluded from receiving pensions or had to move out of houses that they had received for working in the German administration, but no one appears to have been prosecuted by the legal justice system. ${ }^{115}$ Throughout the Soviet period, but also in independent Belarus, the commemoration of Jewish victims-and thus the integration of Jewish and Holocaust history into Belarusian history-has been a thorny issue and is hotly debated, albeit mostly outside of Belarus. ${ }^{116}$ Among others, Belarusian society faces questions about the place of Holocaust memory within or alongside the memory of World War II as a whole, and how to balance commemorating Jewish and non-Jewish victims. In addition, some Belarusians, who were themselves victims of the occupation regime, had become complicit in the victimization of others. Just how to integrate this complexity of wartime experience is a major challenge that Belarus shares with many European countries. ${ }^{117}$ Notably, in a country with a "persistent striving to memorialize victimhood," to acknowledge participation in mass atrocities against one's neighbors still seems impossible. ${ }^{118}$ In this vein, the grave and memorial in the forest symbolize a kind of "negative memory" that cannot be eliminated, yet is difficult to integrate. ${ }^{119}$ They do not acquire a prominent place nor visitors, but remain hidden in the forest, on

113. Pollack, Kontaminierte Landschaften, 40.

114. On the awkward "interplay between stigmatization and memorialization" see Katherine Fleming, "What Remains? Sites of Deportation in Contemporary European Daily Life: The Case of Drancy," in Paolo Giaccaria and Claudio Minca, eds., Hitler's Geographies: The Spatialities of the Third Reich (Chicago, 2016), 359.

115. GAVO, f. 1745, o. 1, d. 9, 1. 1 and 42 (Minutes of Beshenkovichy's Council of Delegates, 1946). A survey of the relevant local newspapers (Zaria and Vitsebskii rabochi) of the years in which trials against local collaborators took place did not yield any articles about people who had worked in Beshankovichy, while (former) residents of other locales stood trial; and archival research has not produced any documentation either.

116. See, for instance, Per Anders Rudling, "The Invisible Genocide: The Holocaust in Belarus," in John-Paul Himka and Joanna B. Michlic, eds., Bringing the Dark Past to Light: The Perception of the Holocaust in Postcommunist Europe (Lincoln, 2013), 71f.

117. See Fleming, "What Remains?,” 358.

118. Serguei Alex. Oushakine, "Postcolonial Estrangements: Claiming a Space Between Stalin and Hitler," in Julie A. Buckler and Emily D. Johnson, eds., Rites of Place: Public Commemoration in Russia and Eastern Europe (Evanston, 2013), 302, 304.

119. Reinhart Koselleck, "Formen und Traditionen des negativen Gedächtnisses," in Volkhard Knigge and Norbert Frei, eds., Verbrechen erinnern: Die Auseinandersetzung mit Holocaust und Völkermord (Munich, 2002), 21. 
the other side of the river. In other towns, mass graves are in full view when the shootings happened at sites that are now located within the town limit but remain unmarked, or memorials are obscured by fences. ${ }^{120}$

The location of the Jews' grave at the outskirts of town continues the exclusion that local Jews experienced during the occupation. It conveniently allows local residents and Belarusian society as a whole to avoid difficult conversations about local responses and behaviors that contributed to, or in many cases even allowed, this exclusion and benefited from it. In contrast, the content and placement of monuments and memorials to others act as "circuits of memory where individual elements can be jettisoned from popular consciousness" and provide physical as much as ideological orientation. ${ }^{121}$ The identifications as a victim, yet ultimately victors, of the German occupation are the result of excluding painful and uncomfortable memories, a pattern that is familiar from the Soviet period but has also survived into the present.

In some way, the focus on, and enthusiasm for, Soviet war memorials, which evoke victimhood at the hands of the German occupation regime and military, resembles a strategy to come to terms with trauma observed in individuals. Rather than facing up to a loss or shock, related experiences are emphasized and used to expunge the traces of the trauma. This kind of "narrative fetishism" signals an "inability or refusal to mourn and is a strategy of undoing, in fantasy, the need for mourning by simulating a condition of intactness, typically by situating the site and origin of loss elsewhere."122 Eric Santner identifies this as a primarily narrative strategy, but it seems reasonable to apply this analysis to interpreting the visual and geographical language of memory-the content and placement of memorials. ${ }^{123}$ In the case of Beshankovichy, the displacement of the loss takes on a literal quality, as the memory of wartime losses is situated in the centrally located memorials for combatants and a small number of local, non-Jewish residents, but removed from where major parts of the local community were killed: on the other side of the river. The displaced loss has a double nature: it is the loss of people who used to live side by side with the remaining population, but it is perhaps also the shame-filled knowledge that some members of the community had turned against their neighbors and had taken part in their extermination.

The dynamics of memory that enable societies of victim-perpetrators to move on, here observed in a small, provincial town, are indicative of how communities in many Soviet localities forged cohesion in the aftermath of war and genocide. They coincided with the overall process of reconstructing

120. See, for instance, a memorial for the mass killing of more than 700 Jews in Mir, ulitsa Oktiabrskaia, in November 1941.

121. Nuala Johnson, “Cast in Stone: Monuments, Geography, and Nationalism," Environment and Planning D: Society and Space 13, no. 1 (1995): 63.

122. Eric L. Santner, "History beyond the Pleasure Principle: Some Thoughts on the Representation of Trauma," in Saul Friedländer, ed., Probing the Limits of Representation: Nazism and the "Final Solution" Cambridge, Mass., 1992), 144 (my emphasis).

123. For another adoption of the concept of "narrative fetishism" to analyze larger societal tendencies in the Soviet and post-Soviet context, see Sergei Ushakin, "Nam etoi bol'iu dyshat'?," in S. Ushakin and E.G. Trubina, eds., Travma: Punkty. Sbornik statei (Moscow, 2009), 17-19. 
Soviet society after the war, an extremely traumatic experience that had to focus on producing coherence and a shared cause to enable continuity. ${ }^{124} \mathrm{This}$ reconstruction could not be based on remembering collaboration because it would have highlighted divisions within the Soviet population.

States regulate access to full citizenship through selection and exclusion or, as in the Soviet case, through the leveling of national (ethnic) distinctions or tensions between different ethnic groups in the service of creating a Soviet identity. Particular modes of memory-in this case, the content and location of Soviet-era memorials and monuments-reflect and establish this process and continue to do so in independent Belarus. ${ }^{125}$ Mechanisms of selection and exclusion are at the heart of the construction of war memory, reflecting the way in which the presence of Jewish culture and people is omitted in historical narratives designed to lay the foundation for Belarusian national identity.

Put differently, the imagined geography of war memory in Beshankovichy, centering literally and figuratively on non-Jewish victims and fallen soldiers, creates a symbolic landscape of memory that rewrites history as a past that binds the current society together by externalizing those who were once part of it and no longer have a significant presence in the local and national population. ${ }^{126}$ It is tragic that the geography of the German project of annihilation colludes with the Soviet politics of memory and nationalities by pushing Jewish history and memory to the margins, and that commemorative practices and the historical discourse in Belarus continue this marginalization of the memory of the Holocaust. ${ }^{127}$

Beshankovichy is a place that reminds us of the different character of the genocide committed in the Soviet territories. Most local Jews were not deported to concentration and extermination camps far away, in the "East." They were rounded up, contained, and killed in or near their hometowns, or, as Tim Cole suggests, in the neighborhood. ${ }^{128}$ Killing sites are thus in close proximity to where the victims had lived, and where their neighbors, classmates, clients, friends, or enemies continued to live after the war. The impact and significance of what it means to live near mass graves has yet to be fully understood. At the same time, the location of these mass graves ought to give us pause. Although close by, they are far enough away from local communities to go unnoticed and to be marginalized in popular practices of commemoration. With them, the last traces of a local past-that of a Jewish community within Beshankovichy and within other Belarusian towns-disappear into oblivion.

124. Saul Friedländer, "History, Memory, and the Historian: Dilemmas and Responsibilities,” New German Critique, Special Issue on the Holocaust, no. 80 (Spring-Summer, 2000), 5.

125. On the alliance between constructions of memory and nation-states, see Macarena Gómez-Barris, Where Memory Dwells: Culture and State Violence in Chile (Berkeley, 2009), 13.

126. See D.W. Meinig, "Symbolic Landscapes: Some Idealizations of American Communities," in D.W. Meinig, ed., The Interpretation of Ordinary Landscapes: Geographical Essays (New York, 1979), 164.

127. See Aliaksei Bratachkin, "Memory of the Holocaust and the Jewish identity in Belarus after 1991,” Belarusian Review, Special Jewish Issue (2016): 90-97; Leonid Smilovitsky, "The attitude toward Holocaust in the former Soviet Union and in modern Belarus," The Point Journal, May 8, 2016, http://thepointjournal.com/output/index. php?art_id=386\&spr_change=eng (last accessed June 12, 2017).

128. Cole, Holocaust Landscapes, 227. 